\title{
Further Genetic Heterogeneity for Autosomal Dominant Human Sutural Cataracts
}

\author{
Norman Klopp a Elise Héonc Gail Billingsleyc Thomas Illig ${ }^{\text {b }}$ \\ Matthias Wjst ${ }^{b}$ Günther Rudolph ${ }^{d}$ J ochen Grawa \\ aGSF National Research Center for Environment and Health, Institutes of Developmental Genetics and \\ bEpidemiology, Neuherberg, Germany; ' Ophthalmology and Visual Scienes, Vision Science Research Program \\ UHN, University of Toronto, Toronto, Canada, and dUniversity Eye Clinic, Ludwig-Maximilians University, \\ Munich, Germany
}

\section{Key Words}

Sutural cataract $\cdot \gamma$-Crystallin - Linkage analysis . Humans · Mutation · Polymorphism

\begin{abstract}
A unique sutural cataract was observed in a 4-generation German family to be transmitted as an isolated autosomal, dominant trait. Since mutations in the $\gamma$-crystallin encoding CRYG genes have previously been demonstrated to be the most frequent reason for isolated congenital cataracts, all 4 active CRYG genes have been sequenced. A single base-pair change in the CRYGA gene has been shown, leading to a premature stop codon. This was not observed in 170 control individuals. However, it did not segregate with the disease phenotype. This is the first truncating mutation in an active CRYG gene without a dominant phenotype. As the CRYGA mutation did not explain the cataract, several other candidate loci (CCV, GJ A8, CRYBB2, BFSP2, MIP, GJ A8, central pouch-like, CRYBA1) were investigated by microsatellite markers and linkage analysis, but they were excluded based on the combination of haplotype analysis and two-point linkage analysis. The phenotype in this family is due to a mutation in another sutural cataract gene yet to be identified.
\end{abstract}

Copyright $@ 2003$ S. Karger AG, Basel

\section{Introduction}

Cataract, an opacification of the eye lens, is a leading cause of visual impairment or blindness during infancy and early childhood [1]. An estimated 200,000 children are blind with bilateral cataract worldwide; 20,000 40,000 children affected with developmental cataract are born each year [2]. In the developed nations of Europe and Northern America, national surveillance or cross-sectional studies revealed a prevalence of 1-4 cases per 10,000 children [3-5].

Most frequently, congenital cataracts without other clinical symptoms have been found in the $\gamma$-crystallin encoding $C R Y G$ genes [6-10]. Moreover, other genes have also been reported to be involved in congenital dominant cataract formation like $C R Y A A[11,12], C R Y B B 2$ [13-15], GJA3 [16], GJA8 [17-19] and BFSB2 (also known as CP49 [20]). Similar clues are observed in the mouse as the most prominent model system for cataract [for an overview, see ref. 21].

Among those mutations listed, only very few have been characterized as sutural opacities. In man, this is a mutation in the CRYBA1 gene [22] and in the mouse the Cat $2^{\text {ns }}$ [23]. We tested for linkage of some of the known cataract loci with the unique phenotype observed in a 4-generation German family. 
Table 1. Haplotype analysis with two-point analysis

\begin{tabular}{|c|c|c|c|c|c|c|c|c|c|c|c|c|c|c|c|c|c|c|c|c|c|}
\hline \multirow{3}{*}{$\begin{array}{l}\text { Marker } \\
C C V\end{array}$} & \multicolumn{21}{|c|}{ Family member } \\
\hline & \multicolumn{2}{|c|}{$\mathrm{I}-2(+)$} & \multicolumn{2}{|c|}{ II-2 (+) } & \multicolumn{2}{|c|}{ II-4 (+) } & \multicolumn{2}{|c|}{ II-5 (-) } & \multicolumn{2}{|c|}{ III-1 (-) } & \multicolumn{2}{|c|}{ III-2 (+) } & \multicolumn{2}{|c|}{ III-3 (+) } & \multicolumn{2}{|c|}{ III-4 (-) } & \multicolumn{2}{|c|}{ IV-1 (+) } & \multicolumn{2}{|c|}{ IV-2 (+) } & \multirow[t]{2}{*}{$\operatorname{LOD}(\Theta=0)$} \\
\hline & & & & & & & & & & & & & & & & & & & & & \\
\hline D1S468 & 2 & 1 & 3 & 1 & 1 & 1 & 1 & 2 & 3 & 1 & 2 & 1 & 2 & 1 & 2 & 1 & 3 & 2 & 1 & 2 & $-\infty$ \\
\hline D1S2845 & 1 & 2 & 6 & 2 & 2 & 2 & 2 & 1 & 5 & 4 & 7 & 2 & 3 & 2 & 3 & 2 & 5 & 7 & 4 & 7 & $-\infty$ \\
\hline D1S508 & 3 & 1 & 5 & 3 & 4 & 1 & 4 & 3 & 1 & 2 & 1 & 3 & 3 & 1 & 3 & 4 & 1 & 1 & 2 & 1 & $-\infty$ \\
\hline \multicolumn{22}{|l|}{ GJA8 } \\
\hline D1S2669 & 1 & 2 & 3 & 1 & 3 & 2 & 3 & 2 & 1 & 3 & 1 & 3 & 1 & 2 & 1 & 2 & 1 & 1 & 3 & 1 & $-\infty$ \\
\hline D1S514 & 1 & 2 & 2 & 1 & 4 & 2 & 4 & 2 & 2 & 2 & 3 & 2 & 2 & 2 & 2 & 2 & 2 & 3 & 2 & 3 & $-\infty$ \\
\hline D1S1595 & 1 & 4 & nd & & 4 & 4 & nd & & nd & & 1 & 4 & 3 & 4 & 4 & 4 & 5 & 4 & 7 & 1 & nd \\
\hline \multicolumn{22}{|l|}{$C R Y G$} \\
\hline D2S2321 & 4 & 2 & 2 & 2 & 2 & 4 & 2 & 4 & 4 & 3 & 3 & 2 & 2 & 2 & 4 & 4 & 4 & 2 & 3 & 2 & 0.85 \\
\hline CRYG & 2 & 2 & 1 & 2 & 1 & 2 & 3 & 2 & 3 & 2 & 2 & 2 & 3 & 1 & 3 & 2 & 3 & 2 & 2 & 2 & $-\infty$ \\
\hline D2S1434 & 4 & 2 & 2 & 2 & 2 & 4 & 2 & 4 & 4 & 3 & 3 & 2 & 2 & 2 & 4 & 4 & 4 & 2 & 3 & 2 & 0.85 \\
\hline \multicolumn{22}{|l|}{$B F S P 2$} \\
\hline D3S606 & 5 & 3 & 6 & 3 & 6 & 5 & 3 & 3 & 6 & 2 & 4 & 6 & 1 & 5 & 7 & 6 & 2 & 6 & 6 & 4 & $-\infty$ \\
\hline D3S3637 & 1 & 2 & 3 & 2 & 3 & 1 & 3 & 2 & 1 & 5 & 4 & 3 & 3 & 1 & 2 & 3 & 5 & 3 & 5 & 3 & $-\infty$ \\
\hline \multicolumn{22}{|l|}{ MIP 26} \\
\hline D12S375 & 3 & 2 & 1 & 2 & 1 & 2 & 1 & 2 & 1 & 3 & 2 & 2 & 2 & 2 & 2 & 2 & 1 & 2 & 3 & 2 & $-\infty$ \\
\hline D12S1052 & 1 & 2 & 2 & 2 & 2 & 2 & 2 & 2 & 2 & 3 & 2 & 2 & 1 & 2 & 1 & 2 & 2 & 2 & 3 & 2 & $-\infty$ \\
\hline D12S1064 & 5 & 4 & 6 & 4 & 2 & 4 & 2 & 4 & 3 & 3 & 6 & 4 & 1 & 4 & 2 & 4 & 3 & 4 & 3 & 6 & $-\infty$ \\
\hline \multicolumn{22}{|l|}{ Gja3 } \\
\hline D13S1316 & 2 & 4 & 6 & 4 & 6 & 2 & 6 & 2 & 1 & 5 & 3 & 4 & 4 & 2 & 4 & 6 & 5 & 4 & 1 & 4 & $-\infty$ \\
\hline D13S175 & 2 & 2 & 3 & 2 & 3 & 2 & 3 & 2 & 2 & 3 & 1 & 2 & 4 & 2 & 5 & 3 & 3 & 2 & 2 & 2 & 1.51 \\
\hline D13S1275 & 5 & 1 & 3 & 1 & 3 & 5 & 3 & 5 & 4 & 1 & 1 & 3 & 2 & 5 & 6 & 3 & 4 & 3 & 4 & 3 & $-\infty$ \\
\hline D13S2332 & 3 & 1 & 2 & 1 & 2 & 3 & 2 & 3 & 2 & 4 & 3 & 2 & 2 & 3 & 2 & 2 & 2 & 2 & 2 & 2 & $-\infty$ \\
\hline \multicolumn{22}{|l|}{ CPC } \\
\hline D15S659 & 4 & 2 & 2 & 2 & 2 & 4 & 2 & 4 & 1 & 2 & 2 & 2 & 4 & 2 & 3 & 4 & 1 & 2 & 1 & 2 & -0.1 \\
\hline D15S643 & 3 & 1 & 2 & 1 & 3 & 3 & 2 & 3 & 2 & 1 & 3 & 2 & 3 & 3 & 4 & 3 & 2 & 2 & 2 & 2 & $-\infty$ \\
\hline D15S153 & 3 & 4 & 1 & 4 & 4 & 3 & 1 & 3 & 2 & 4 & 5 & 1 & 2 & 4 & 1 & 3 & 2 & 1 & 2 & 1 & $-\infty$ \\
\hline \multicolumn{22}{|l|}{$C R Y B A 3$} \\
\hline D17S122 & 2 & 2 & 3 & 2 & 3 & 2 & 3 & 2 & 1 & 3 & 4 & 2 & 3 & 2 & 3 & 3 & 3 & 4 & 3 & 2 & $-\infty$ \\
\hline D17S1294 & 4 & 2 & 1 & 2 & 1 & 4 & 1 & 2 & 3 & 2 & 2 & 2 & 2 & 4 & 2 & 1 & 3 & 2 & 2 & 2 & $-\infty$ \\
\hline$C R Y B B 2$ & & & & & & & & & & & & & & & & & & & & & \\
\hline D22S431 & 2 & 3 & 3 & 3 & 1 & 3 & 1 & 3 & 4 & 3 & 3 & 3 & 4 & 3 & 1 & 3 & 4 & 3 & 3 & 3 & $-\infty$ \\
\hline D22S258 & 3 & 2 & 2 & 2 & 2 & 2 & 2 & 2 & 1 & 2 & 2 & 2 & 1 & 2 & 1 & 2 & 1 & 3 & 2 & 3 & $-\infty$ \\
\hline
\end{tabular}

'+’ = Affected; '-' = unaffected; $\mathrm{nd}=$ not determined.

\section{Materials and Methods}

\section{Clinical Documentation}

The proband and the accompanying parents or relatives underwent clinical eye examination by a senior pediatric ophthalmologist at the Eye Clinic of the Ludwig-Maximilians University of Munich, Germany, by either Scheimpflug (Topcon-SL45) or slit lamp (Zeiss, Oberkochen, Germany) examination. Clinical details were recorded in a standard questionnaire including the age of onset and time of diagnosis of the cataract in the proband as well as the proband's and her family's health history. This study respected the tenets of the Declaration of Helsinki, as the family members were fully informed of their role in the study and the outcome, prior to securing their informed consent, prepared according to standard norms.

\section{Molecular Analysis}

Blood samples $(5-10 \mathrm{ml})$ were collected from the affected and unaffected members of the family and genomic DNA was isolated according to standard procedures. Candidate loci were analyzed by a combination of linkage analysis and haplotype analysis as well as by mutational analysis of the coding sequence available for selected genes. Specifically, the $\gamma$-crystallin gene cluster $(C R Y G)$ was analyzed by sequencing. PCR of the four active $C R Y G$ genes $(C R Y G A$, $C R Y G B, C R Y G C, C R Y G D$ ) was performed on genomic DNA sam- 
ples in reactions of $20 \mu \mathrm{l}$ with a denaturation step at $95^{\circ} \mathrm{C}$ for $2 \mathrm{~min}$, for 1 cycle, followed by 40 cycles of $95^{\circ} \mathrm{C}$ denaturation for $45 \mathrm{~s}$, annealing at $60^{\circ} \mathrm{C}$ for $45 \mathrm{~s}$, extension at $72^{\circ} \mathrm{C}$ for $45 \mathrm{~s}$ and with a final extension at $72^{\circ} \mathrm{C}$ for $5 \mathrm{~min}$ with either a Stratagene Robocycler (Stratagene, Heidelberg, Germany) or a Perkin Elmer Thermocyler (Perkin Elmer, Weiterstadt, Germany), using primers according to Santhiya et al. [10]. Sequence analysis was performed commercially (SequiServe, Vaterstetten, Germany) after purification of PCR fragments through Nucleospin ${ }^{\circledR}$ extraction columns (Macherey-Nagel, Düren, Germany). The interesting sequence variation suggestive of a mutation was further investigated by restriction analysis ( $\mathrm{N} v a \mathrm{II})$.

Mapping of Candidate Loci and Linkage Analysis

In addition to the $C R Y G$ gene cluster, a group of candidate genes/ loci was selected from their previously documented association with sutural lens opacities (table 1). Polymorphic markers were selected from the publicly available databases to cover the genetic intervals of interest. The most informative markers used are listed in table 1.

Assuming an autosomal dominant mode of inheritance and complete penetrance, our family was not powerful enough to detect significant linkage (LOD score $>3$, odds for linkage of at least 1,000:1; $p=0.05$ ). The power to detect linkage was investigated using SLINK. Two hundred replicates of the pedigree were generated assuming a completely penetrant $\mathrm{AD}$ disease locus with disease allele frequency of 0.01 and no phenocopies. The predicted maximum LOD score is 2.10 (average 1.60); however, the structure of the family allowed us to obtain significant information by haplotype analysis.

Genotyping was done masked to the disease status. Genetic maps used for the selection of short tandem repeat polymorphisms were obtained from the literature, those characterized by the Cooperative Human Linkage Center (www.chcl.org/), Généthon (www.genethon.fr/) and others available through the Internet, such as Marshfield (www.marshmed.org/genetics/) and GDB. Primers were obtained from Research Genetics Inc. (screening set 6A), ACGT Inc., or Dalton Inc. (Toronto, Canada). A fluorescent dye label was incorporated on the 5 '-end of one of the primers and the amplification products were electrophoresed using ALF automated sequencers (Pharmacia, Piscataway, USA) and analyzed using the fragment manager software. The amplification protocol has previously been described [14]. Their intermarker distances (cM) were determined from genome database genetic maps.

Cyrillic (V2.1.3) was used for data management and pedigree drawing. Two-point linkage analysis between the cataract phenotype and the genotype information used the MLINK component of LINKAGE (v5.1 [24]). A full penetrance and a disease-gene frequency of 0.0001 were assumed for the disease locus. The allele frequencies were assumed to be equal for each marker since the true population allele frequencies for each marker could not be reliably estimated.

\section{Results and Discussion}

\section{Phenotype Description}

A 4-generation family (fig. 1) with the clinical feature of progressive congenital sutural cataract (cataract stellaris) was examined at the Eye Hospital of the Ludwig-Maximilians University, Munich, Germany. The phenotype

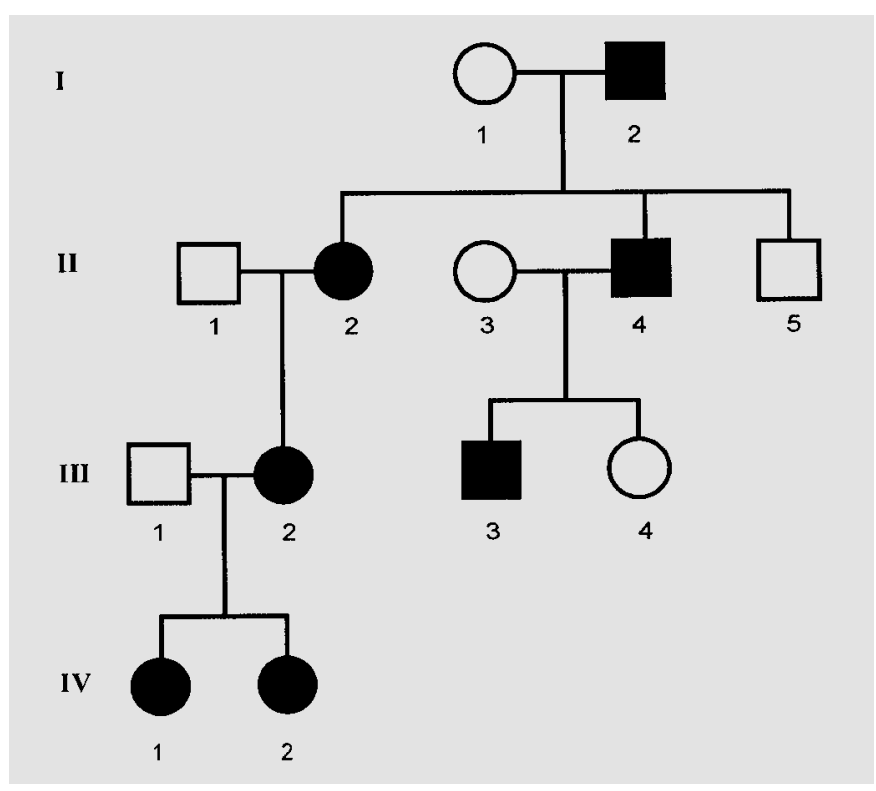

Fig. 1. Pedigree of the sutural cataract family. The pedigree of the 4-generation German family demonstrates the autosomal dominant mode of inheritance. The numbers next to the patient's symbol indicate the collected blood sample used for linkage or molecular analysis.

of two sisters (IV/1, IV/2) was analyzed by skiascopy, slit lamp examination, funduscopy and documented with a Scheimpflug camera (fig. 2) and with a slit lamp camera (fig. 3; Zeiss, Oberkochen, Germany).

In the older sister (IV/1; fig. 1), visual acuity for distance and near on the right eye was $20 / 50$ (cc. $+3.0 /-2.0 /$ $175^{\circ}=0.4$ ) and on the left eye $20 / 50$ (cc. $+3.0 /-2.0 /$ $\left.180^{\circ}=0.4\right)$. The cornea was clear and the anterior chamber without irregularities. The lens showed dense opacities of the anterior and posterior $\lambda$-suture and a diffuse moderate opacification of the whole lens. Vitreous and retina were normal. Binocular vision was reduced (Titmus fly + ; Bagolini + ; Titmus rings up to ring 2, normally ring 9), and the symbols on the Lang chart could not be recognized.

Cataract extraction with intraocular lens implantation was performed successfully. Postoperative visual acuity with best correction was $0.8(20 / 25)$ on both eyes. Moderate reduction of postoperative visual acuity is explained by a relative amblyopia.

In the younger sister (IV-2), visual acuity was $20 / 40$ with best correction of $+2.5 /-0.5 / 180^{\circ}$ on the right eye $(0.5)$ and on the left eye $0.6(20 / 30)$ with a correction of $+2.0 /-0.75 / 175^{\circ}$. The lens also showed dense opacities of 
Fig. 2. Scheimpflug analysis. The Scheimpflug pictures show dense opacities of the lens more prominent at the anterior than the posterior $\lambda$-suture. The spots in the anterior chamber (b) are artifacts due to reflexions. The age of the patients were 16 (a; IV-1) and 11 (b; IV-2) years.
Left Eye
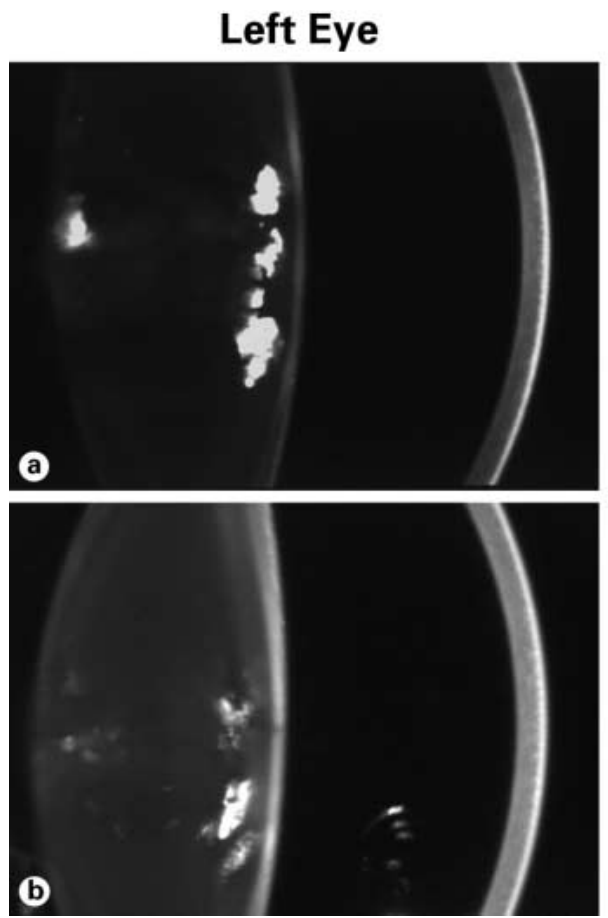

Right Eye
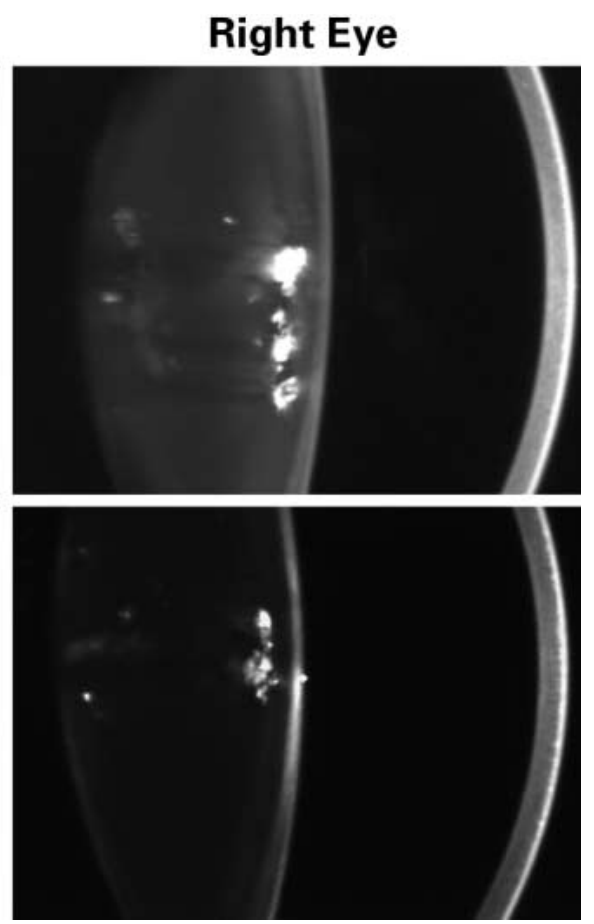

the $\lambda$-sutures and moderate diffuse opacification of the lens and the nucleus. Binocular vision was nearly identical to her sister. The Titmus rings were recognized up to ring 3 (Titmus fly + , Bagolini + ), and cataract surgery is planned. In both patients, no strabismus was present.

The mother (III/2) of the two girls demonstrated at the age of 42 years less opacities in the $\lambda$-suture but snowflake-like subcapsular opacities in the central as well as in the more peripheral areas of the lens and diffuse opacification of the whole lens, but the overall severity was not significantly different from her daughters (fig. 3). Functional testing in the mother was not performed; she was operated in 1998 at another hospital. In all family members, no further clinical manifestations were observed cosegregating with the ocular phenotype, suggesting that the cataract in this family was an isolated feature.

\section{Analysis of the CRYG Candidate Genes}

Since it has been shown in mouse and man that $C R Y G$ genes are most frequently causative for congenital, isolated cataracts, we sequenced all 4 active human $C R Y G$ genes also in the proband and her father. In two of the four $C R Y G$ genes (CRYGA, CRYGD), we observed polymorphic changes. The $\mathrm{T} \rightarrow \mathrm{C}$ transversion at position 196 of the $C R Y G A$ gene (exon 3) leads to a Pro instead of a Lys. However, this Pro is very common in human (10 of 10 cases tested in a previous study [10]) and in all other Cryg genes of mouse, rat and bovine. Two further polymorphic sites have been observed in the CRYGD gene (AG9293GA; QV $\rightarrow$ QM; T286C without effect on the amino acid composition); both have also been observed in a previous study [10] with a high frequency and without cosegregation with congenital cataracts. All three polymorphisms were also observed in the proband's father. In contrast, the described silent polymorphic site in the $C R Y G B$ gene at position 2437 (ccC $\rightarrow$ ccT; Pro $\rightarrow$ Pro; acc. M19364 [6]) could not be observed in the proband nor in her father.

However, an additional insertion of $\mathrm{C}$ at position 43 in the $C R Y G A$ was observed in the proband (IV-1, fig. 4) in a heterozygous situation. The mutation leads to a shift of the open reading frame; computer-assisted translation suggests that only a short peptide will be formed consisting of the $13 \mathrm{~N}$-terminal amino acids of the $\gamma \mathrm{A}$-crystallin and 7 novel amino acids (fig. 4). Since all other previously reported truncations of the Cryg genes in the mouse lead to dominant cataracts, this mutation was suggested to be causative for the phenotype in this family. Using a restriction enzyme digestion by AvaII, we could find this particular polymorphism neither in additional 170 randomly collected human DNA samples of Caucasian origin nor in 1 Indian family suffering from dominant cataracts (C132 
Left Eye
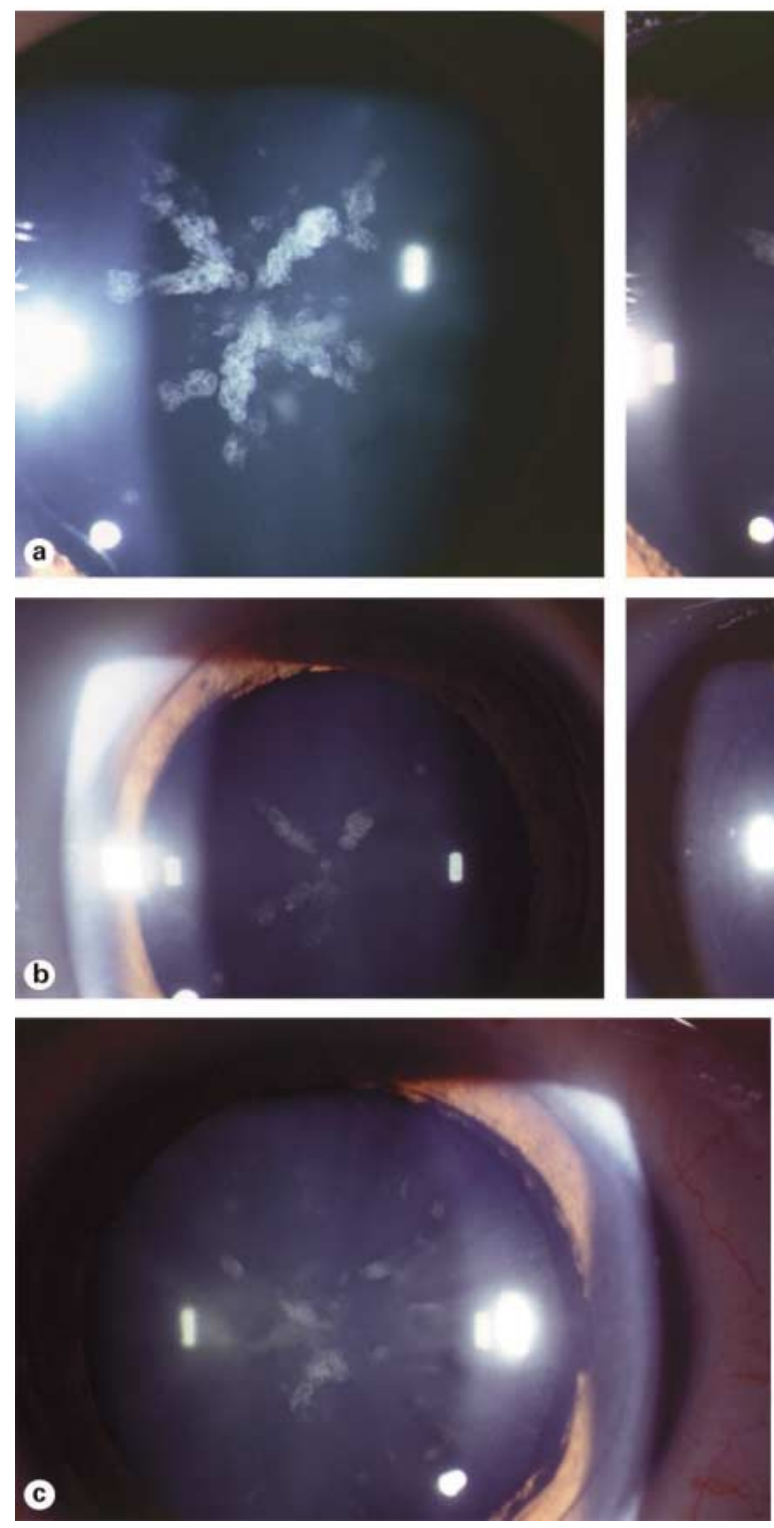

Right Eye
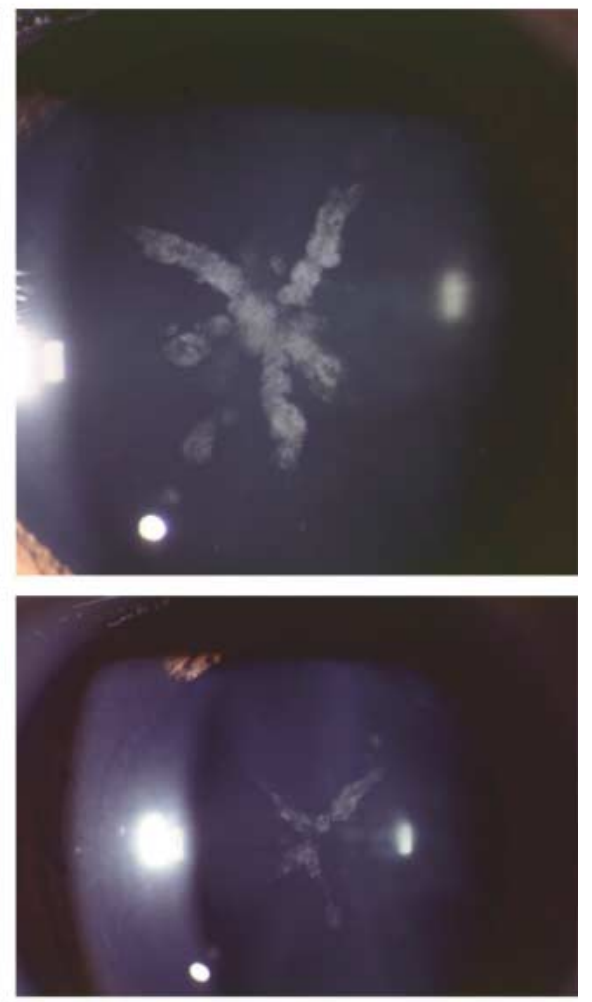

Fig. 3. Slit-lamp analysis. Dense opacifications were presently more expressed at the anterior $\lambda$-suture.. The anterior and posterior suture are demonstrated in their inverse position. There is also a diffuse opacification of the whole lens as compared with young individuals of the same age. The age of the patients were 16 (a; IV-1) and 11 (b); IV-2) years; the age of the mother (c; III-2) was 42 years.

[10]). However, the sequence change observed did not segregate with the disease phenotype and was observed only in the proband and her unaffected father, but in none of the other affected members of the family; we conclude that this particular polymorphism is very rare $(<1 \%$; fig. 5).

To our knowledge, it is the first truncating $C R Y G$ change without (dominant) consequences on the clinical phenotype. It might be speculated that this small peptide (18 amino acids) is either unstable and will be degraded or does not have a dominant negative effect as described in the other truncated $\gamma$-crystallin, which have usually a molecular weight of $16-18 \mathrm{kD}$ [25-27]. As in the $\psi C R Y G E$ and $\psi C R Y G F$, the loss of function of a further $C R Y G$ gene also seems to be without pathological consequences. However, the mouse Cryga gene is expressed earlier (from E12.5 onward) and at a higher level than the other Cryg genes [28]. From this point of view, it would be expected that mutations in the Cryga gene should lead to severe cataracts. However, there has been no report on a $C R Y G A$ mutation in man so far, and also in the mouse, only one mutation has been reported [25]. In the human 


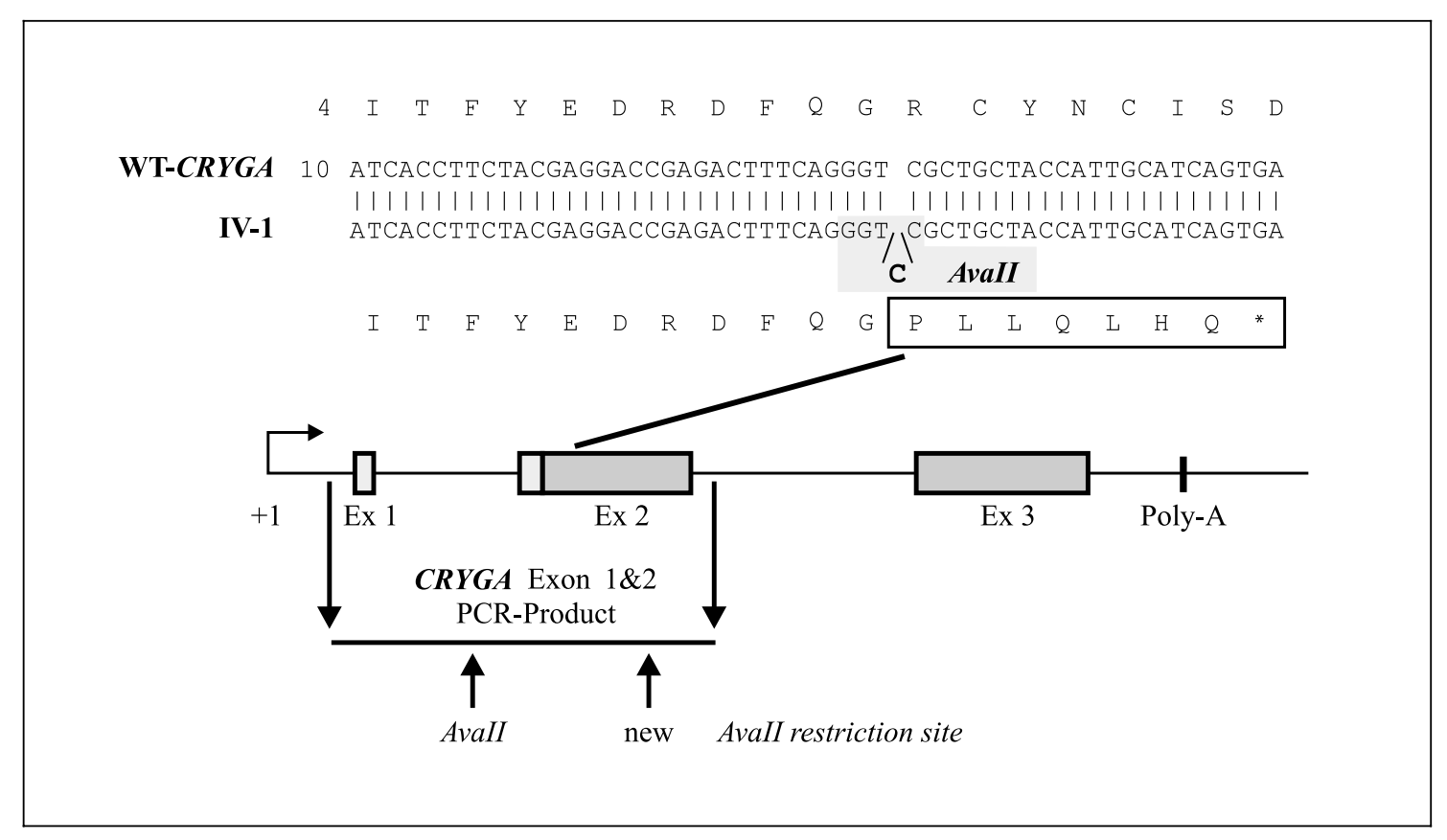

Fig. 4. Sequence analysis of $C R Y G A$, exon 2. Sequence analysis of exon 2 of the $C R Y G A$ gene in the proband (IV-1) revealed an insertion of a $\mathrm{C}$ at position 43 (given in bold, counted according to its position in the cDNA). It leads to a short peptide of just 20 amino acids including 7 foreign amino acids (boxed) because of a stop codon in the new reading frame. The genomic $C R Y G$ gene structure is indicated below the DNA and deduced amino acid sequence. The new AvaII restriction site is shaded in grey; the place of the regular and new AvaII sites are indicated below the genomic structure.

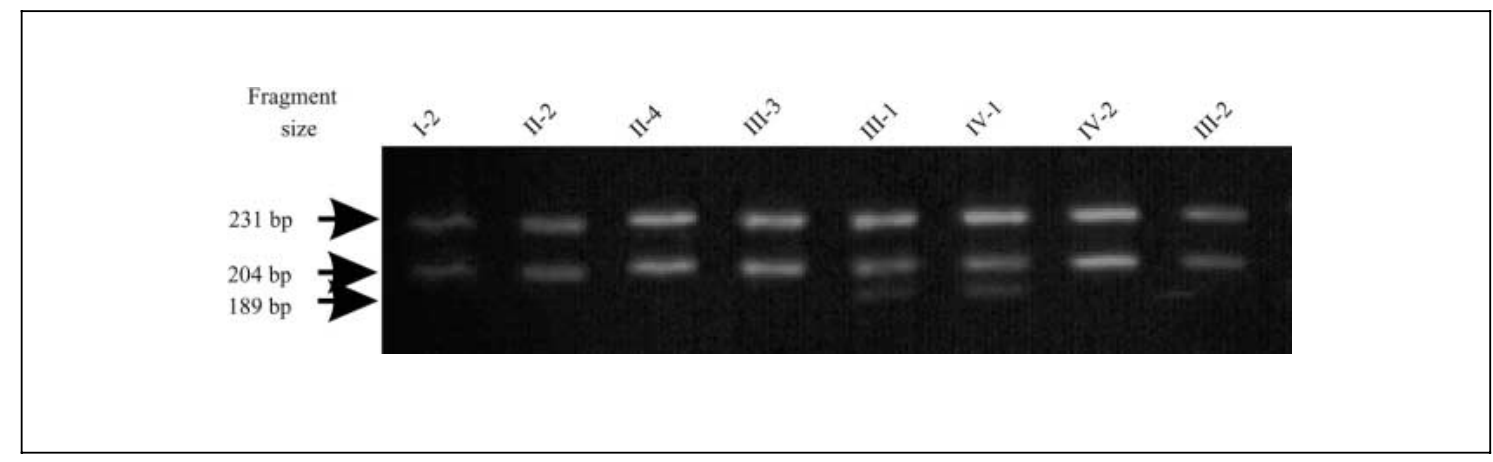

Fig. 5. Restriction digest of $C R Y G A$ by $A v a \mathrm{II}$. The $A v a \mathrm{II}$ restriction analysis of the PCR fragment containing exons 1 and 2 are given. The carriers of the insertion (III-1 and IV-1) demonstrate 3 bands indicating the presence of two restriction sites, whereas all other affected family members exhibit only two bands indicating the presence of just one restriction site.

embryonic lens, $C R Y G A$ contributes $14 \%$ to the overall $C R Y G$ transcripts (for comparison: $C R Y G C$ and $C R Y G D$ together $81 \%, C R Y G B$ only $5 \%$ [29]). Therefore, the contribution of $C R Y G A$ to the functional integrity of the lens is less compared with $C R Y G C$ and $C R Y G D$.

\section{Linkage of the Cataract Phenotype to Known Cataract Loci}

Following the sequence analysis of the $C R Y G$ genes, we proceeded to the genetic analysis of the other sutural cataract candidate loci (table 1). Using linkage analysis 
and haplotype analysis, the candidate loci considered were genetically excluded, suggesting another sutural cataract locus is yet to be identified.

\section{Conclusion}

A specific form of sutural opacities has been observed in a 4-generation German family. A newly found truncation of the $\gamma$ A-crystallin after 20 amino acids is not involved in the formation of this type of cataract. Map- ping experiments did not show linkage to known sutural cataract loci. This suggests that this unique form of sutural opacity represents a novel genetic subtype expanding the genetic heterogeneity of this condition.

\section{Acknowledgment}

The expert technical assistance of Margret Bahnweg and Erika Bürkle is gratefully acknowledged. Oligonucleotides have been manufactured by Utz Linzner (working group Bioinformatics at the GSF Institute of Experimental Genetics).

\section{References}

1 Francis PJ, Berry V, Bhattacharya SS, Moore AT: The genetics of childhood cataract. J Med Genet 2000;37:481-488.

2 Foster A, Gilbert C, Rahl J: Epidemiology of cataract in childhood: A global perspective. J Cataract Refract Surg 1997;23:601-604.

3 James LM: Maps of birth defects occurrence in the US, Birth Defects Monitoring Program (BDMP)/CPHA, 1970-1987. Teratology 1993 . 48:551-646.

4 Stoll C, Alembik Y, Dott B, Roth MP: Congenital eye malformations in 212,479 consecutive births. Ann Genet 1997;40:122-128.

5 Abrahamson M, Magnusson G, Sjöstrom A, Popovic Z, Sjöstrand J: The occurrence of congenital cataract in western Sweden. Acta Ophthalmol Scand 1999;77:578-580.

6 Héon E, Priston M, Schoderet DF, Billingsley GD, Girard PO, Lubsen N, Munier FL: The $\gamma$ crystallins and human cataracts: A puzzle made clearer. Am J Hum Genet 1999;65: 1261-1267.

7 Stephan DA, Gillanders E, Vanderveen D, Freas-Lutz D, Wistow G, Baxevanis AD, Robbins CM, van Auken A, Quesenberry MI, Bailey-Wilson J, Juo SH, Trent HM, Smith L, Brownstein MJ: Progressive juvenile-onset punctate cataracts caused by mutation of the $\gamma D$-crystallin gene. Proc Natl Acad Sci USA 1999;96:1008-1012.

8 Kmoch S, Brynda J, Asfaw B, Bezouska K, Novák P, Rezácová $\mathrm{P}$, Ondrová L, Filipec M, Sedlácek J, Elleder M: Link between a novel human $\gamma \mathrm{D}$-crystallin allele and a unique phenotype explained by protein crystallography. Hum Mol Genet 2000;9:1779-1786.

9 Ren Z, Li A, Shastry BS, Padma T, Ayyagari R, Scott MH, Parks MM, Kaiser-Kupfer MI, Hejtmancik JF: A 5-base insertion in the $\gamma \mathrm{C}$-crystallin gene is associated with the autosomal dominant variable zonular pulverulent cataract. Hum Genet 2000;106:531-537.

10 Santhiya ST, Manohar MS, Rawlley D, Vijayalaksmi P, Namperumalsamy P, Gopinath PM, Löster J, Graw J: Novel mutations in the $\gamma$-crystallin genes cause autosomal dominant congenital cataracts. J Med Genet 2002;39: 352-358.
11 Litt M, Kramer P, LaMorticella DM, Murphey W, Lovrien EW, Weleber RG: Autosomal dominant congenital cataract associated with a missense mutation in the human $\alpha$-crystallin gene CRYAA. Hum Mol Genet 1998;7:471474.

12 Pras E, Frydman M, Levy-Nissenbaum E, Bakham T, Raz J, Assia EI, Goldman B, Pras E: A nonsense mutation (W9X) in CRYAA causes autosomal recessive cataract in an inbred Jewish Persian family. Invest Ophthalmol Vis Sci 2000;41:3511-3515.

13 Litt M, Carrero-Valenzuela R, La Morticella DM, Schultz DW, Mitchell TN, Kramer P, Maumenee IH: Autosomal dominant cerulean cataract is associated with a chain termination mutation in the human $\beta$-crystallin gene CRYBB2. Hum Mol Genet 1997;6:665-668.

14 Gill D, Klose R, Munier FL, McFadden M, Priston M, Billingsley G, Ducray N, Schorderet DF, Héon E: Genetic heterogeneity of the Coppock-like cataract: A mutation in $C R Y B B 2$ on chromosome 22q11.2. Invest Ophthalmol Vis Sci 2000;41:159-165.

15 Vanita, Sarhadi V, Reis A, Jung M, Singh D, Sperling K, Singh JR, Bürger J: A unique form of autosomal dominant cataract explained by gene conversion between $\beta$-crystallin $\mathrm{B} 2$ and its pseudogene. J Med Genet 2001;38:392-396.

16 Rees MI, Watts P, Fenton I, Clarke A, Snell RG, Owen MJ, Gray J: Further evidence of autosomal dominant congenital zonular pulverulent cataracts linked to $13 \mathrm{q} 11(\mathrm{CZP} 3)$ and a novel mutation on connexin 46 (GJA3). Hum Genet 2000;106:206-209.

17 Shiels A, Mackay D, Ionides A, Berry V, Moore A, Bhattacharya S: A missense mutation in the human connexin50 gene (GJA8) underlies autosomal dominant 'zonular pulverulent' cataract on chromosome 1q. Am J Hum Genet 1998;62:526-532.

18 Berry V, Mackay D, Khaliq S, Francis PJ, Hameed A, Anwqar K, Mehdi SQ, Newbold RJ, Ionides A, Shiels A, Moore T, Bhattacharya SS: Connexin 50 mutation in a family with congenital 'zonular nuclear' pulverulent cataract of Pakistani origin. Hum Genet 1999;105:168170.
19 Polyakov AV, Shagina IA, Khlebnikova OV, Evgrafov OV: Mutation in the connexin 50 gene $(G J A 8)$ in a Russian family with zonular pulverulent cataract. Clin Genet 2001;60:476478.

20 Jakobs PM, Hess JF, FitzGerald PG, Kramer P, Weleber RG, Litt M: Autosomal-dominant congenital cataract associated with a deletion mutation in the human beaded filament protein gene BFSP2. Am J Hum Genet 2000;66: 1432-1436.

21 Graw J, Löster J: Developmental genetics in ophthalmology. Ophthalmic Genet, in press.

22 Kannabiran C, Rogan PK, Olmos L, Basti S, Rao GN, Kaiser-Kupfer M, Hejtmancik JF: Autosomal dominant zonular cataract with sutural opacities is associated with a splice mutation in the $\beta A 3 / A 1-c r y s t a l l i n$ gene. Mol Vis 1998; 4:18.

23 Graw J: Mouse models of congenital cataract. Eye 1999;13:438-444.

24 Lathrop G, Lalouel J: Easy calculations of LOD scores and genetic risk on small computers. Am J Hum Genet 1984;36:460-465.

25 Klopp N, Favor J, Löster J, Lutz RB, Neuhäuser-Klaus A, Prescott A, Pretsch W, Quinlan RA, Sandilands A, Vrensen GFJM, Graw J: Three murine cataract mutants (Cat2) are defective in different $\gamma$-crystallin genes. Genomics 1998;52:152-158.

26 Klopp N, Löster J, Graw J: Characterization of a 1-bp deletion in the $\gamma$ E-crystallin gene leading to a nuclear and zonular cataract in the mouse. Invest Ophthalmol Vis Sci 2001;42:183-187.

27 Graw J, Neuhäuser-Klaus A, Löster J, Klopp N, Favor J: Ethylnitrosourea-induced base pair substitution affects splicing of the mouse $\gamma \mathrm{E}$ crystallin encoding gene leading to the expression of a hybrid protein and to cataract. Genetics 2002; 161:1633-1640.

28 Sandilands A, Hutcheson AM, Long HA, Prescott AR, Vrensen G, Löster J, Klopp N, Lutz RB, Graw J, Masaki S, Dobson CM, MacPhee CE, Quinlan RA: Altered aggregation properties of mutant $\gamma$-crystallins cause inherited cataract. EMBO J 2002;21:6005-6014.

29 Brakenhoff RH, Aarts HJM, Reek FH, Lubsen NH, Schoenmakers JGG: Human $\gamma$-crystallin genes - a gene family on its way to extinction. $\mathrm{J}$ Mol Biol 1990;216:519-532. 